\title{
Seed exudates of Sesbania virgata (Cav.) Pers. stimulate the asymbiotic phase of the arbuscular mycorrhizal fungus Gigaspora albida Becker \& Hall
}

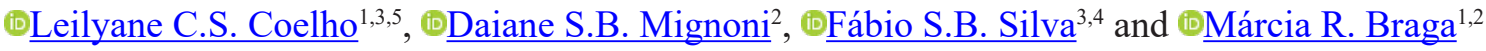

Received: 15 March 2018; accepted: 13 September 2018

How to cite: Coelho, L.C.S., Mignoni, D.S.B., Silva, F.S.B. \& Braga, M.R. 2019. Seed exudates of Sesbania virgata (Cav.) Pers. stimulate the asymbiotic phase of the arbuscular mycorrhizal fungus Gigaspora albida Becker \& Hall. Hoehnea 46: e272018. http://dx.doi.org/10.1590/2236-8906-27/2018.

\begin{abstract}
Seed exudates of Sesbania virgata (Cav.) Pers. stimulate the asymbiotic phase of the arbuscular mycorrhizal fungus Gigaspora albida Becker \& Hall). Sesbania virgata is a legume used in the restoration of degraded areas and forms a symbiosis with arbuscular mycorrhizal fungi (AMF). Its seeds exude secondary metabolites that may influence the colonization by AMF. In this work, we studied the effects of seed (SE) and root exudates (RE) of S. virgata on the asymbiotic phase of Gigaspora albida. Spores of G. albida were germinated in medium supplemented with different concentrations of SE or RE. After seven days, spore germination was stimulated (46.6\%) in the medium supplemented with the highest concentration of SE, while the mycelial growth was stimulated with the lowest SE concentration. In turn, RE had no effect on the fungal asymbiotic phase. We concluded that SE exert a positive effect on the asymbiotic phase of G. albida and that the different effects between SE and RE of $S$. virgata can be explained by their distinct content of secondary metabolites.

Keywords: germination, Glomeromycota, mycelial growth, plant exudation
\end{abstract}

RESUMO - (Exsudatos de sementes de Sesbania virgata (Cav.) Pers. estimulam a fase assimbiótica do fungo micorrízico arbuscular Gigaspora albida Becker \& Hall). Sesbania virgata é uma leguminosa utilizada na restauração de áreas degradadas e que forma simbiose com fungos micorrízicos arbusculares (AMF). Suas sementes exudam metabólitos secundários que podem influenciar a colonização pelos AMF. Neste trabalho, estudamos os efeitos de exsudatos de sementes (SE) e radiculares (RE) de S. virgata na fase assimbiótica de Gigaspora albida. Esporos de G. albida foram germinados em meio suplementado com diferentes concentrações de SE ou RE. Após sete dias, a germinação dos esporos foi estimulada (46,6\%) com a maior concentração de SE, enquanto o crescimento micelial foi estimulado com a menor concentração de SE. Por sua vez, RE não teve efeito na fase assimbiótica de G. albida. Conluiu-se que SE exercem efeitos positivos na fase assimbiótica de G. albida e que os efeitos diferenciais entre SE e RE de $S$. virgata na fase de assimbiótica fúngica podem ser explicados pelo seu conteúdo distinto de metabólitos secundários. Palavras-chave: crescimento micelial, exudação de plantas, germinação, Glomeromycota

\section{Introduction}

Arbuscular mycorrhizal fungi (AMF), soil fungi of the sub-phylum Glomeromycotina (phylum Mucoromycota) (Spatafora et al. 2016), associate with plant roots and promote the growth of the host and the exchange of nutrients that are fundamental for the symbiotic association. Through interaction with the fungus, not only phosphorus (P) and nitrogen (N) but also micronutrients such as zinc $(\mathrm{Zn})$, copper $(\mathrm{Cu})$ and iron $(\mathrm{Fe})$ are supplied to the plant. In turn, the AMF benefits from the plant carbohydrates (Bucher et al. 2009, Garg \& Chandel 2010).

The establishment of symbiosis in the compatible host plants allows AMF to complete their life cycle. Such fungi are obligatory biotrophs, which life cycle starts with the germination of spores, which are formed in the soil or within the roots (Maia \& Yano-

1. Universidade Estadual de Campinas, Instituto de Biologia, Biologia Celular e Estrutural, Campinas, SP, Brasil

2. Instituto de Botânica, Núcleo de Pesquisa em Fisiologia e Bioquímica, São Paulo, SP, Brasil

3. Universidade de Pernambuco, Laboratório de Enzimologia e Fitoquímica Aplicada à Micologia, Campus Petrolina, Petrolina, PE, Brasil

4. Universidade de Pernambuco, Instituto de Ciências Biológicas, Biologia Celular e Molecular Aplicada, Campus Santo Amaro, Recife, PE, Brasil

5. Corresponding author: leilyane.coelho@upe.br 
Melo 2001, Souza et al. 2010). Studies have shown that the molecular dialogue between the symbionts precedes the physical contact and the molecules, which are produced by plants and fungi, are involved in the communication process (Kiriachek et al. 2009, Bonfante \& Requena 2011).

Before establishing symbiosis, the AMF develop the asymbiotic phase (or pre-symbiotic), which consists of germination, formation of germination tubes and limited production of asymbiotic mycelium. This phase can be affected by physical, chemical and biological factors (Maia et al. 2010). During this phase, the fungus uses triglyceride reserves, one of the main forms of AMF carbon storage (Bago et al. 2000, Requena et al. 2007).

Each spore formed by the Glomeromycotina constitutes one unique, multinucleated cell with a diameter varying from 22 to $1050 \mu \mathrm{m}$ (Souza et al. 2010), which shows a particular physiology. The spore is able to germinate and interrupt growth in the soil many times, even in the absence of the host signals (Requena et al. 2007, Willis et al. 2013). Even though the AMF spores have the metabolic capacity for germination and limited growth of the hyphae, such events are maximized when environmental and endogenous inducing factors are favorable (Nagahashi $\&$ Douds 2000).

Compounds that are present in the root exudates of the host plants stimulate spore germination, hyphal growth and ramification, and its nuclear division (Buee et al. 2000, Bücking et al. 2008, Ellouze et al. 2012). Akiyama et al. (2005) isolated an inducing ramification factor of root exudates of Lotus japonicus and identified it as a strigolactone (5-deoxy-strigol), responsible for morphogenetic changes that convert germination tubes with limited growth into presymbiotic mycelium with the capacity to initiate colonization of susceptible roots.

The majority of studies concerning the asymbiotic phase of AMF have focused on the effects of root exudates; however, there are only a few reports on the effects of seed exudates (Tsai \& Phillips 1991). Souza Filho et al. (2011) documented the importance of seeds as an alternative source of chemical compounds with allelopathic activity, considering that they represent positive signals for symbiosis with microorganisms in the soil. Secondary metabolites that are produced by seeds also play a role in the symbiotic association of certain legumes and nitrogen-fixing bacteria (Ndakidemi \& Dakora 2003).
Sesbania virgata (Fabaceae) is a shrubby legume that produces a large number of seeds, which are viable for a long time and exudate secondary metabolites at the beginning of the imbibition process. The main metabolite exuded by $S$. virgata seeds is the flavonoid $(+)$-catechin, found in the testa and released in high concentrations on the first day of imbibition (Simões et al. 2008). S. virgata is used for restoration of degraded areas due to its rusticity, availability of seeds and the capacity to establish symbiosis with rhizobia and AMF, which favors nutrient absorption in soils with low fertility (Potomati \& Buckeridge 2002, Araújo et al. 2004, Schiavo et al. 2009, Bomfeti et al. 2013). However, the effects of its crude seed (SE) and root exudates (RE) on the asymbiotic phase of AMF have not been evaluated.

Studies have been conducted aiming evaluate the effects of different compounds on the asymbiotic growth stages of AMF with a focus on species of the genera Gigaspora and Glomus (Tawaraya et al. 1996, Oba et al. 2002, Scervino et al. 2009, Cantor et al. 2011, De Jaeger et al. 2011). In this study the hypothesis that SE and RE of $S$. virgata can exert an influence on the asymbiotic phase of Gigaspora albida was tested. For that, we examined the effects of crude $\mathrm{SE}$ and RE of Sesbania virgata on spore germination and in vitro mycelial growth of G. albida.

\section{Material and methods}

Crude seed exudates (SE) of Sesbania virgata - $S$. virgata seeds (1000 seeds) were selected based on coat color (light brown) and size (about $5 \mathrm{~mm}$ long) and manually scarified with the use of sanding paper (P80 $3 \mathrm{M})$. Seeds were then superficially disinfected four times by immersion in a $10 \%$ sodium hypochlorite solution (Super Cândida ${ }^{\circledR}, 2 \%$ active chlorine) for $20 \mathrm{~min}$ and washed with sterile distilled water. In a laminar flow chamber, seeds were distributed in $150 \mathrm{~mm}$ glass Petri dishes (50 seeds/dish) containing qualitative filter paper $\left(\right.$ Qualy $\left.{ }^{\circledR}\right)$, soaked in sterile distilled water $(35 \mathrm{~mL})$. The dishes were transferred to a germination chamber (BOD model 347 FG, Fanem ${ }^{\circledR}$ ) at $25^{\circ} \mathrm{C}$ and $12 \mathrm{~h}$ photoperiod. After $48 \mathrm{~h}$, the crude SE of $S$. virgata were collected and aliquoted in different volumes for posterior lyophilization.

Crude root exudates (RE) of Sesbania virgata - Seeds of $S$. virgata were germinated as described above and, after 6 days in the germination chamber, 300 plantlets were transferred to polyethylene pots ( 5 per pot) filled with $500 \mathrm{~g}$ of autoclaved quartz as a substrate. The pots 
were maintained in a greenhouse and watered daily with distilled water $(50 \mathrm{~mL})$, a volume below to field capacity. Nutritive Hoagland solution $(50 \mathrm{~mL})$ was given to the plantlets at the first day of the experiment. After 5 days, each pot was watered with a fixed volume of distilled water $(100 \mathrm{~mL})$, superior to field capacity, and the leachates were collected to obtain the crude RE. The exudates were aliquoted in different volumes for posterior lyophilization.

Analysis of Sesbania virgata exudates - Soluble carbohydrates, total proteins, total phenols and total flavonoids were determined in the crude SE and RE of S. virgata. The soluble carbohydrates were quantified by the phenol-sulfuric method (Dubois et al. 1956), using glucose $\left(\operatorname{Vetec}^{\circledR}\right)$ as a standard. Total protein was quantified using the Bradford colorimetric method (1976), using a Bovine Serum Albumin $\left(\right.$ Sigma $\left.^{\circledR}\right)$ as standard and total phenols were quantified with the Folin-Ciocalteau $\left(\right.$ Merck $\left.^{\circledR}\right)$ method using tannic acid $\left(\right.$ Sigma $^{\circledR}$ ) as the standard (Monteiro et al. 2006). Total flavonoids were quantified according to Araújo et al. (2008) using rutin $\left(\right.$ Sigma $\left.^{\circledR}\right)$ as standard.

Aliquots of the crude aqueous SE of $S$. virgata were also fractionated with ethyl acetate $(2: 1$ $\mathrm{v} / \mathrm{v})$. The remaining water in the collected organic fraction was removed by drying with anhydrous sodium sulfate $\left(\right.$ Sigma $\left.^{\circledR}\right)$. Subsequently, the organic solution was filtered, concentrated by evaporation and dissolved in $1 \mathrm{~mL}$ of methanol for analysis by liquid chromatography in combination with mass spectrometry (LC/MS) as described by Simões et al. (2008). The peaks were compared with $(+)$-commercial catechin $\left(\right.$ Sigma $\left.^{\circledR}\right)$ (figure 1).

In vitro germination assay of Gigaspora albida Different volumes of crude SE and RE of $S$. virgata were lyophilized and then resuspended in $3 \mathrm{~mL}$ of distilled water to obtain different concentrations: 1 (2.8 $\mu \mathrm{g}$ catechin $\left.\mathrm{mL}^{-1}\right), 2\left(8.4 \mu \mathrm{g}\right.$ catechin $\left.\mathrm{mL}^{-1}\right), 3(13.9 \mu \mathrm{g}$ catechin $\left.\mathrm{mL}^{-1}\right), 4\left(19.5 \mu \mathrm{g}\right.$ catechin $\left.\mathrm{mL}^{-1}\right)$ and 5 (27.9 $\mu \mathrm{g}$ catechin $\left.\mathrm{mL}^{-1}\right)$ of SE and $1\left(0.1 \mu \mathrm{g}\right.$ catechin $\left.\mathrm{mL}^{-1}\right)$, $2\left(0.4 \mu \mathrm{g}\right.$ catechin $\left.\mathrm{mL}^{-1}\right), 3\left(0.7 \mu \mathrm{g}\right.$ catechin $\left.\mathrm{mL}^{-1}\right), 4$ $\left(1.0 \mu \mathrm{g}\right.$ catechin $\left.\mathrm{mL}^{-1}\right)$ and $5\left(1.4 \mu \mathrm{g}\right.$ catechin $\left.\mathrm{mL}^{-1}\right)$ for RE. All solutions were filtered under sterile conditions using a $0.22 \mu \mathrm{m}$ membrane, before being aseptically incorporated into the medium.

The control was prepared with the aseptic incorporation of the same quantity of distilled water to the water agar medium. G. albida spores isolated from the soil, according to Gerdemann \& Nicolson (1963) and Jenkins (1964), were used for inoculation. The spores were obtained from the AMF inoculum bank of Laboratory of Enzymology and Phytochemistry Applied to Mycology, University of Pernambuco, Petrolina, Brazil. In a laminar flow chamber, the selected AMF spores were disinfected in a sodium hypochlorite solution $(0.05 \% / 2 \mathrm{~min})$ and washed four times in sterile distilled water (Nuutila et al. 1995). Groups of five superficially disinfected spores were transferred individually to Petri dishes containing $8 \mathrm{~mL}$ of water agar medium $(2.0 \%)$ autoclaved at $121{ }^{\circ} \mathrm{C}$, $15 \mathrm{~min}$ and supplemented with the $S$. virgata exudates (SE and RE). The dishes were sealed with Parafilm $\mathrm{M}^{\circledR}$, wrapped in aluminum foil and incubated at room temperature $\left(28 \pm 2{ }^{\circ} \mathrm{C}\right)$ and relative air humidity of $60-80 \%$. At 7 and 14 days after inoculation, the percentage of spore germination was examined and the mycelial length ( $\mathrm{mm} /$ germinated spore) was determined according to Newman (1966), under a stereomicroscope $(40 \times)$, after staining of the hyphae with an aqueous solution of Trypan blue ( $0.05 \%)$. For each type of crude exudates (SE and RE) of $S$. virgata, the experimental design was entirely randomized with six concentrations of exudates of $S$. virgata in 4 repetitions, totalizing 24 experimental plots per evaluation time ( 7 and 14 days).
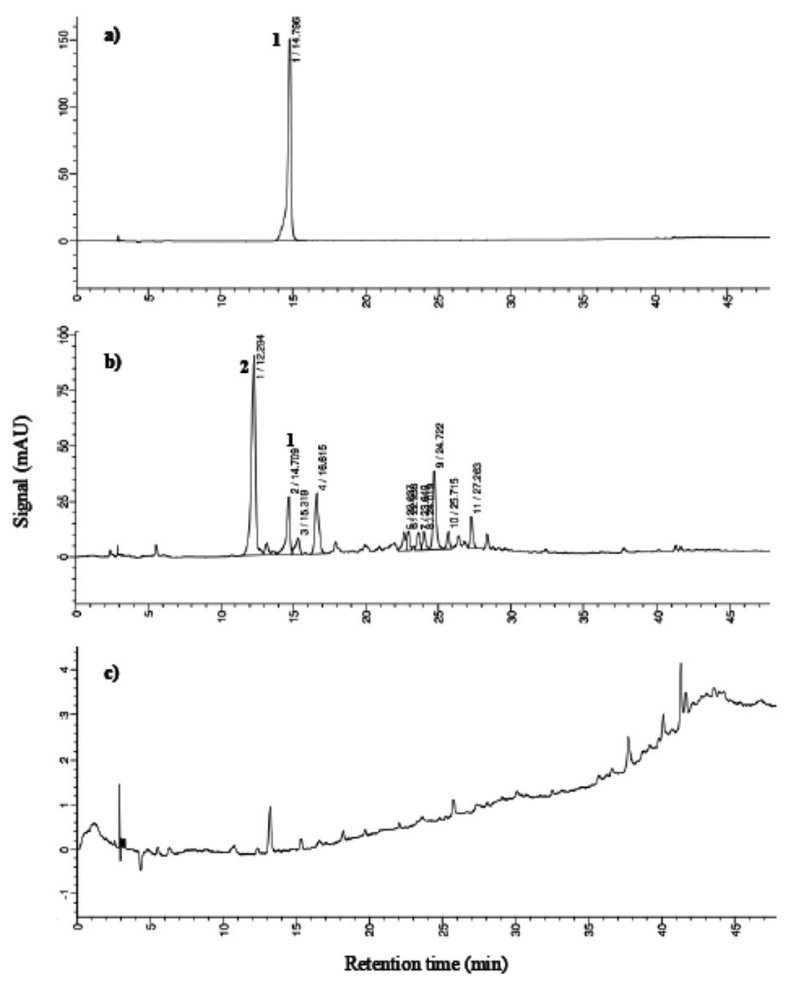

Figure 1. LC/MS profile of commercial catechin (a), seed exudates (b) and root exudates (c) of Sesbania virgata. Peaks: 1: catechin (retention time $14.7 \mathrm{~min}$ ); 2: catechin dimer (retention time 12.3 $\min )$. 
Under the same experimental conditions mentioned above, an assay was carried out with a stock solution of $(+)$-commercial catechin $\left(\right.$ Sigma $\left.^{\circledR}\right)$, in a concentration of $280 \mu \mathrm{g} \mathrm{mL}^{-1}$, based on the $(+)$-catechin concentration of that was detected in the crude SE of $S$. virgata, a value approximately $95 \%$ higher compared to the crude RE (data not shown). To determine if such compound exerts effects on the asymbiotic phase of G. albida, the experimental design was entirely randomized with six treatments $(0,2.8$, $8.4,14.0,19.5$, and $28.0 \mu \mathrm{g}$ catechin $\mathrm{mL}^{-1}$ ), in four repetitions.

Experiment and analysis sites - Department of Plant Physiology and Biochemistry, Institute of Botany, São Paulo, Brazil (crude exudates of $S$. virgata production); Laboratory of Enzymology and Phytochemistry Applied to Mycology, University of Pernambuco, Petrolina, Brazil (exudates of $S$. virgata analysis and spore germination/hyphal growth of $G$. albida); Chemical Institute, University of São Paulo, São Paulo, Brazil (LC/MS profile of commercial catechin and exudates of $S$. virgata).

Statistical analysis - The data were submitted to ANOVA and when appropriate the averages were compared by the Tukey-test $(\mathrm{P}<0.05)$ using the ASSISTAT program, version 7.6 beta (Silva 2008).

\section{Results}

In the presence of crude SE of S. virgata, germination of G. albida spores varied from 20 to $46.6 \%$ after 7 days and from 20 to $60 \%$ on the $14^{\text {th }}$ day of incubation (table 1), which indicates the viability of the spores. The medium supplemented with the highest concentration of exudates $\left(27.9 \mu \mathrm{g}\right.$ catechin $\left.\mathrm{mL}^{-1}\right)$ stimulated spore germination (46.6\%) after 7 days, but his stimulation was not observed on the $14^{\text {th }}$ day. High mycelial growth $(0.69 \mathrm{~mm} /$ germinated spore $)$ was observed in the medium supplemented with the lowest exudates concentration $\left(2.8 \mu \mathrm{g}\right.$ catechin $\left.\mathrm{mL}^{-1}\right)$, after 7 days; however, on the $14^{\text {th }}$ day, the presence of crude SE did not interfere in the production of asymbiotic mycelium of G. albida (table 2).

There was no significant effect of the crude RE on spore germination of and mycelial growth of G. albida, independently of the time of examination (tables 1 and 2).

Higher concentrations of soluble carbohydrates, proteins, phenols, and flavonoids were found in the crude SE of $S$. virgata corresponding to 298.6, 28.4, 104.8 and $0.012 \mathrm{mg} \mathrm{mL}^{-1}$, respectively, when compared to the crude RE $(33.9,4.2,0$ and $0.004 \mathrm{mg}$ $\mathrm{mL}^{-1}$, respectively).

The presence of catechin and a catechin dimer was confirmed in SE and RE, although in lower amounts in RE (figure 1). Commercial catechin used as a control in the assays had no effects on the asymbiotic phase of G. albida (data not shown).

\section{Discussion}

Compounds present in the SE of $S$. virgata favored the germination of G. albida spores. The characterization of the exudates confirmed that different compounds were leaked by seeds, mainly sugars, probably as result of the mobilization of the storage carbohydrates that occur at the beginning of the imbibition process as reported by Buckeridge \& Dietrich (1996). Besides sugars, phenolic compounds present in the exudates can also have promoted spore germination. Simões et al. (2008) observed that

Table 1. Percentage of in vitro germination of Gigaspora albida spores in water agar medium supplemented with different concentrations of crude seed (SE) and root exudates (RE) of Sesbania virgata at seven and 14 days after inoculation.

Treatments

SE of S. virgata $\left(\mu \mathrm{g}\right.$ catechin $\left.\mathrm{mL}^{-1}\right)$

\begin{tabular}{lcccccc}
\hline Time (days) & 0 & 2.8 & 8.4 & 13.9 & 19.5 & 27.9 \\
\hline 7 & $20.0 \mathrm{~b}$ & $20.0 \mathrm{~b}$ & $33.3 \mathrm{ab}$ & $33.3 \mathrm{ab}$ & $30.0 \mathrm{ab}$ & $46.7 \mathrm{a}$ \\
14 & $46.7 \mathrm{ab}$ & $60.0 \mathrm{a}$ & $45.0 \mathrm{ab}$ & $53.3 \mathrm{ab}$ & $20.0 \mathrm{c}$ & $33.3 \mathrm{bc}$ \\
\hline \multicolumn{7}{l}{ RE of $S$. virgata $\left(\mu\right.$ g catechin $\left.\mathrm{mL}^{-1}\right)$} \\
\hline 7 days $($ days) & 0 & 0.1 & 0.4 & 0.7 & 1.0 & 1.4 \\
14 days & $15.0 \mathrm{a}$ & $10.0 \mathrm{a}$ & $15.0 \mathrm{a}$ & $5.0 \mathrm{a}$ & $10.0 \mathrm{a}$ & $0 \mathrm{a}$ \\
\hline
\end{tabular}

Averages followed by the same letter in lines do not differ by the Tukey test $(P<0.05)$. 
Table 2. In vitro mycelial growth ( $\mathrm{mm} /$ germinated spore) of Gigaspora albida spores in water agar medium supplemented with different concentrations of crude seed (SE) and root exudates (RE) of Sesbania virgata at seven and 14 days after inoculation.

Treatments

SE of $S$. virgata $\left(\mu\right.$ g catechin $\left.\mathrm{mL}^{-1}\right)$

\begin{tabular}{lcccccc}
\hline Time (days) & 0 & 2.8 & 8.4 & 13.9 & 19.5 & 27.9 \\
\hline 7 & $0 \mathrm{~b}$ & $0.69 \mathrm{a}$ & $0.18 \mathrm{~b}$ & $0 \mathrm{~b}$ & $0 \mathrm{~b}$ & $0 \mathrm{~b}$ \\
14 & $0.93 \mathrm{a}$ & $0.49 \mathrm{a}$ & $0.66 \mathrm{a}$ & $0.41 \mathrm{a}$ & $1.28 \mathrm{a}$ & $0.58 \mathrm{a}$ \\
\hline \multicolumn{7}{c}{ RE of S. virgata $\left(\mu\right.$ catechin $\left.\mathrm{mL}^{-1}\right)$} \\
\hline Time (days) & 0 & 0.1 & 0.4 & 0.7 & 1.0 & 1.4 \\
\hline 7 & $0.03 \mathrm{a}$ & $0 \mathrm{a}$ & $0.08 \mathrm{a}$ & $0 \mathrm{a}$ & $0 \mathrm{a}$ & $0 \mathrm{a}$ \\
\hline
\end{tabular}

Averages followed by the same letter in lines do not differ by the Tukey test $(\mathrm{P}<0.05)$.

$(+)$-catechin was quickly released from the seed coat of $S$. virgata on the first day of imbibition at higher levels than those documented for other species of Sesbania (Ceballos et al. 1998).

In our study, we used the direct collection method of crude exudates without the conventional extraction with organic solvents or even fractionation. Bücking et al. (2008) concluded that the crude root exudates differ in their effect on the pre-symbiotic growth of AMF from those that are partially purified. The authors showed that crude exudates accelerate spore germination of Glomus intraradices and also stimulated the ramification of the germination tubes; when exudates from partially purified roots were added, the spores germinated lately but the number of ramifications after 14 days did not differ from the control.

Similar to the results present in this work (table 1), Tahat et al. (2010) found differences in the germination of Glomus mosseae supplied with different root exudates. The authors suggested that these differences were due to the quality and the source of the exudate. Spore germination was stimulated by increasing amounts of non-mycorrhizal root exudates of tomato and corn.

Present findings show that only SE were efficient in stimulating the mycelial growth of G. albida (table 2), which suggests the existence of signal substances that stimulate the hyphal ramification in the leachates of $S$. virgata seeds.

There are situations in which root exudates stimulate the hyphal ramification of germinated spores of Gigaspora species (Buee et al. 2000, Nagahashi \& Douds 2000, Akiyama et al. 2005), which diverges from the results obtained in our experiments. In these studies, the root exudates of all examined plant species showed an inductive activity of the hyphal ramification, with the exception of exudates from nonhost roots. However, generalizations about the effects of exudates should be avoided and the type, the dosage and the stage of the asymbiotic phase (germination or mycelial growth) must be taken into consideration.

Studies have shown that flavonoids are components of root exudates capable of stimulating spore germination, mycelial growth, and ramification of various AMF. In many cases, they are also responsible for mycorrhizal colonization, for active molecular mechanism of the root colonization and for establishing symbiosis (Gianinazzi-Pearson et al. 1989, Nair et al. 1991, Siqueira et al. 1991, Romero \& Siqueira 1996, Soares et al. 2005, Scervino et al. 2009). However, it was found that, by using chalcone synthase-deficient corn mutants, a key-enzyme in the biosynthesis of flavonoids, these compounds are not essential for establishing arbuscular mycorrhizal symbiosis (Bécard et al. 1995, Buee et al. 2000, Bécard et al. 2004). The characterization of the exudates that were used in the present study points to small, available concentrations of these compounds, which suggests the presence of other substances than flavonoids are responsible for activating the asymbiotic phase of G. albida. The complex composition of SE, verified by LC/MS analysis (figure 1), suggests that multiple compounds that are exuded by the seeds could be responsible for the stimulating effect that was observed in the asymbiotic phase of G. albida, as was documented by Siqueira et al. (1991) for G. margarita. It is reasonable to 
suppose that such molecules can act in a synergic way resulting in the asymbiotic mycelial production observed (table 2). In this regard, Tsai \& Phillips (1991) reported that naturally exuded flavonoids from alfalfa seeds (Medicago sativa L.) promoted the in vitro germination of Glomus etunicatum and Glomus macrocarpum spores.

The flavonoid $(+)$-catechin is the main metabolite exuded by $S$. virgata seeds. It is found in the seed coat and liberated in high concentrations $(235 \mu \mathrm{g}$ of $(+)$-catechin/seed), after $24 \mathrm{~h}$ of imbibition (Simões et al. 2008). However, such molecule did not stimulate the asymbiotic phase of G. albida (data not shown), indicating that probably other exuded molecules are involved in the stimulation of the fungal asymbiotic phase. Studies with other AMF isolates are still necessary to determine the beneficial effect of $S$. virgata exudates. Only the isolation, chemical characterization and assays using isolated compounds will help to identify whether the effect of $S$. virgata exudates is due specifically to one substance or to a combination of several substances.

In conclusion, our results show that $\mathrm{SE}$ and $\mathrm{RE}$ of $S$. virgata exert a distinct influence on the asymbiotic phase of G. albida, stimulating spore germination when the medium is supplemented with SE. This effect could not be attributed to catechin, which is exuded by seeds of $S$. virgata at the beginning of the imbibition process, but is rather related to other compounds found in SE.

\section{Acknowledgments}

This work is part of the Ph.D. thesis of L.C.S. Coelho at the Post-Graduate Program in Cellular and Structural Biology, University of Campinas, SP (Brazil) and was supported by CAPES/DINTER and CAPES/PROAP. Thanks are due to Conselho Nacional de Desenvolvimento Científico e Tecnológico (CNPq, Grant 474325/2009-1) and Fundação de Amparo a Pesquisa do Estado de São Paulo (FAPESP, Grants 2005/04139-7 and 2012/16332-0), which also supported the work. M.R. Braga acknowledges CNPq for the research fellowship. We are grateful to Dra. Maria Angela Machado de Carvalho for English revision and useful comments on the manuscript.

\section{Literature cited}

Akiyama, K., Matsuzaki, K. \& Hayashi, H. 2005. Plant sesquiterpenes induce hyphal branching in arbuscular mycorrhizal fungi. Nature 435: 824-827.
Araújo, E.C., Mendonça, A.V.R., Barroso, D.G., Lamônica, K.R. \& Silva, R.F. 2004. Caracterização morfológica de frutos, sementes e plântulas de Sesbania virgata (Cav.) Pers. Revista Brasileira de Sementes 26: 105-110.

Araújo, T.A.S., Alencar, N.L., Amorim, E.L.C. \& Albuquerque, U.P. 2008. A new approach to study medicinal plants with tannins and flavonoids contents from the local knowledge. Journal of Ethnopharmacol 120: 72-80.

Bago, B., Pfeffer, P.E. \& Shachar-Hill, Y. 2000. Carbon metabolism and transport in arbuscular mycorrhizas. Plant Physiology 124: 949-957.

Bécard, G., Taylor, L.P., Douds, D.D.Jr., Pfeffer, P.E. \& Doner, L.W. 1995. Flavonoids are not necessary plant signal compounds in arbuscular mycorrhizal symbioses. Molecular Plant-Microbe Interactions Journal 8: 252-258.

Bécard, G., Kosuta, S., Tamasloukht, M., SéjalonDelmas, N. \& Roux, C. 2004. Partner communication in the arbuscular mycorrhizal interaction. Canadian Journal of Botany 82: 1186-1197.

Bomfeti, C.A., Ferreira, P.A.A., Carvalho, T.S., De Rycke, R., Moreira, F.M.S., Goormachtig, S. \& Holsters, M. 2013. Nodule development on the tropical legume Sesbania virgata under flooded and non-flooded conditions. Plant Biology 15: 93-98.

Bonfante, P. \& Requena, N. 2011. Dating in the dark: how roots respond to fungal signals to establish arbuscular mycorrhizal symbiosis. Current Opinion in Plant Biology 14: 451-457.

Bradford, M.M. 1976. A rapid and sensitive method for the quantitation of microgram quantities of protein utilizing the principle of protein-dye binding. Analytical Biochemistry 72: 248-254.

Bucher, M., Wegmüller, S. \& Drissner, D. 2009. Chasing the structures of small molecules in arbuscular mycorrhizal signaling. Current Opinion in Plant Biology 12: 500-507.

Buckeridge, M.S. \& Dietrich, S.M.C. 1996. Mobilisation of the raffinose family oligosaccharides and galactomannan in germinating seeds of Sesbania marginata Benth. (Leguminosae-Faboideae). Plant Science 117: 33-43.

Bücking, H., Abubaker, J., Govindarajulu, M., Tala, M., Pfeffer, P.E., Nagahashi, G., Lammers, P. \& Shachar-Hill, Y. 2008. Root exudates stimulate the uptake and metabolism of organic carbon in germinating spores of Glomus intraradices. New Phytologist Journal 180: 684-695.

Buee, M., Rossignol, M., Jauneau, A., Ranjeva, R. \& Bécard, G. 2000. The pre-symbiotic growth of arbuscular mycorrhizal fungi is induced by a branching factor partially purified from plant root exudates. Molecular Plant-Microbe Interactions Journal 13: 693-698. 
Cantor, A., Hale, A., Aaron, J., Traw, M.B. \& Kalisz, S. 2011. Low allelochemical concentrations detected in garlic mustard-invaded forest soils inhibit fungal growth and AMF spore germination. Biological Invasions 13: 3015-3025.

Ceballos, L., Hossaert-Mckey, M., Mckey, D. \& Andary, C. 1998. Rapid deployment of allelochemicals in exudates of germinating seeds of Sesbania (Fabaceae): roles of seed anatomy and histolocalization of polyphenolic compounds in anti-pathogen defense of seedlings. Chemoecology 8: 141-151.

De Jaeger, N., De la Providencia, I.E., Rouhier, H. \& Declerck, S. 2011. Co-entrapment of Trichoderma harzianum and Glomus sp. within alginate beads: impact on the arbuscular mycorrhizal fungi life cycle. Journal of Applied Microbiology 111: 125-135.

Dubois, M., Gilles, K.A., Hamilton, J.K., Rebers, P.A. \& Smith, F. 1956. Colorimetric method for determination of sugars and related substances. Analytical Chemistry 28: 350-356.

Ellouze, W., Hamel, C. Cruz, A.F., Ishii, T., Gan, Y., Bouzid, S. \& St-Arnaud, M. 2012. Phytochemicals and spore germination: At the root of AMF host preference? Applied Soil Ecology 60: 98-104.

Garg, N. \& Chandel, S. 2010. Arbuscular mycorrhizal networks: process and functions. A review. Agronomy Sustainable Development 30: 581-599.

Gerdemann, J.W. \& Nicolson, T.H. 1963. Spores of mycorrhizal Endogone species extracted from soil by wet sieving and decanting. Transactions of the British Mycological Society 46: 235-244.

Gianinazzi-Pearson, V., Branzanti, B. \& Gianinazzi, S. 1989. In vitro enhancement of spore germination in early hyphal growth of a vesicular-arbuscular mycorrhizal fungus by host root exudates plants and flavonoids. Symbiosis 7: 243-255.

Kiriachek, S.G., Azevedo, L.C.B. Peres, L.E.P. \& Lambais, M.R. 2009. Regulação do desenvolvimento de micorrizas arbusculares. Revista Brasileira Ciência do Solo 33: 1-16.

Jenkins, W.R. 1964. A rapid centrifugal-flotation technique for separating nematodes from soil. Plant Disease Report 48: 692.

Maia, L.C. \& Yano-Melo, A.M. 2001. Germination and germ tube growth of the arbuscular mycorrhizal fungi Gigaspor albida in different substrates. Brazilian Journal of Microbiology 32: 281-285.

Maia, L.C., Silva, F.S.B. \& Goto, B.T. 2010. Estrutura, ultraestrutura e germinação de glomerosporos. pp. 75-118. In: J.O. Siqueira, F.A. Souza, E.J.B.N. Cardoso, \& S.M. Tsai (eds.). Micorrizas: 30 anos de pesquisa no Brasil. Editora UFLA, Lavras.
Monteiro, J.M., Albuquerque, U.P., Lins Neto, E.M.F., Araújo, E.L., Albuquerque, M.M. \& Amorim, E.L.C. 2006. The effects of seasonal climate changes in the Caatinga on tannin levels in Myracrodruon urundeuva (Engl.) Fr. All. and Anadenanthera colubrina (Vell.) Brenan. Revista Brasileira de Farmacognosia 16: 338-344.

Nagahashi, G. \& Douds Jr, D.D. 2000. Partial separation of root exudates components and their effects upon the growth of germinated spores of AM fungi. Mycological Research 104: 1453-1464.

Nair, M.G., Safir, G.R. \& Siqueira, J.O. 1991. Isolation and identification of vesicular-arbuscular mycorrhizastimulatory compounds from clover (Trifolium repens) roots. Applied and Environmental Microbiology 57: 434-439.

Ndakidemi, P.A. \& Dakora, F.D. 2003. Legume seed flavonoids and nitrogenous metabolites as signals and protectants in early seedling development. Functional Plant Biology 30: 729-745.

Newman, E.I. 1966. A method of estimating the total length of root in a sample. Journal of Applied Ecology 3: 139.

Nuutila, A.M., Vestberg, M. \& Kauppinen, V. 1995. Infection of hairy roots strawberry (Fragaria $\mathrm{x}$ Ananassa Duch.) with arbuscular mycorrhizal fungus. Plant Cell Reports 14: 505-509.

Oba, H., Tawaraya, K. \& Wagatsuma, T. 2002. Inhibition of pre-symbiotic hyphal growth of arbuscular mycorrhizal fungus Gigaspora margarita by root exudates of Lupinus spp. Soil Scienceand Plant Nutrition 48: 117-120.

Potomati, A. \& Buckeridge, M.S. 2002. Effect of abscisic acid on the mobilization of galactomannan and embryo development of Sesbania virgata (Cav.) Pers. (Leguminosae-Faboideae). Revista Brasileira de Botânica 25: 303-310.

Requena, N., Serrano, E., Ocón, A. \& Breuninger, M. 2007. Plant signals and fungal perception during arbuscular mycorrhiza establishment. Phytochemistry 68: 33-40.

Romero, A.G.F. \& Siqueira, J.O. 1996. Atividade de flavonóides sobre esporos do fungo micorrízico Gigaspora gigantea in vitro. Pesquisa Agropecuária Brasileira 31: 517-522.

Scervino, J.M., Ponce, M.A., Monica, I.D., Vierheilig, H., Campo, J.A.O. \& Godeas, A. 2009. Development of arbuscular mycorrhizal fungi in the presence of different patterns of Trifolium repens shoot flavonoids. Journal of Soil Science and Plant Nutrition 9: 102-115.

Schiavo, J.A., Martins, M.A. \& Rodrigues, L.A. 2009. Avaliação nutricional de mudas de Acacia mangium, Sesbania virgata e Eucalyptus camaldulensis inoculadas com fungos micorrízicos, em casa de vegetação e em cava de extração de argila. Acta Scientiarum Agronomy 31: 701-707. 
Silva, F.A.S. 2008. Sistema de Assistência Estatística ASSISTAT versão 7.6 beta (em linha). Departamento de Engenharia Agrícola/DEAG, CTRN, Universidade Federal de Campina Grande/UFCG, Paraíba, Brasil, Campina Grande. Disponível em: http://www.assistat. com/.

Simões, K., Du, J., Kretzschmar, F.S., Broeckling, C.D., Stermitz, F.S., Vivanco, J.M. \& Braga M.R. 2008. Phytotoxic catechin leached by seeds of the tropical weed Sesbania virgata. Journal of Chemical Ecology 34: 681-687.

Siqueira, J.O., Safir, G.R. \& Nair, M.G. 1991. Stimulation of vesicular-arbuscular mycorrhiza formation and growth of white clover by flavonoid compounds. New Phytologist 118: 87-93.

Soares, A.C.F., Martins, M.A., Mathias, L. \& Freitas, M.S.M. 2005. Arbuscular mycorrhizal fungi and the occurrence of flavonoids in roots of passion fruit seedlings. Scientia Agricola 62: 331-336.

Souza, F.A., Stürmer, S.L., Carrenho, R. \& Trufem, S.F.B. 2010. Classificação e taxonomia de fungos micorrízicos arbusculares e sua diversidade e ocorrência no Brasil. pp. 15-73. In: J.O. Siqueira, F.A. Souza, E.J.B.N. Cardoso \& S.M. Tsai (eds.). Micorrizas: 30 anos de pesquisa no Brasil. Editora UFLA, Lavras.
Souza Filho, A.P.S., Trezzi, M.M. \& Inoue, M.H. 2011. Sementes como fonte alternativa de substâncias químicas com atividade alelopática. Planta Daninha 29: 709-716.

Spatafora, J.W., Chang, Y., Benny, G.L., Lazarus, K., Smith, M.E., Berbee, M.L., Bonito, G., Corradi, N., Grigoriev, I., Gryganskyi, A., James, T.Y., O'Donnell, K., Roberson, R.W., Taylor, T.N., Uehling, J., Vilgalys, R., White, M.M. \& Stajich, J.E. 2016. A phylum-level phylogenetic classification of zygomycete fungi based on genome-scale data. Mycologia 108: 1028-1046.

Tahat, M.M., Sijam, K. \& Othman, R. 2010. The role of tomato and corn root exudates on Glomus mosseae spores germination and Ralstonia solanacearum growth in vitro. International Journal of Plant Pathology 1: 1-12.

Tawaraya, K., Watanabe, S., Yoshida, E. \& Wagatsuma, T. 1996. Effect of onion (Allium cepa) root exudates on the hyphal growth of Gigaspora margarita. Mycorrhiza 6: 57-59.

Tsai, S.M. \& Phillips, D.A. 1991. Flavonoids released naturally from alfalfa promote development of symbiotic Glomus spores in vitro. Applied and Environmental Microbiology 57: 1485-1488.

Willis, A., Rodrigues, B.F. \& Harris, P.J.C. 2013. The ecology of arbuscular mycorrhizal fungi. Critical Reviews in Plant Sciences 32: 1-20. 